\title{
Bovine colostrum: Changes in lipid constituents in the first 5 days after parturition
}

\author{
G. Contarini, ${ }^{1}$ M. Povolo, V. Pelizzola, L. Monti, A. Bruni, L. Passolungo, F. Abeni, and L. Degano \\ Consiglio per la ricerca e la sperimentazione in agricoltura-Centro di ricerca per le produzioni foraggere e lattiero casearie (CRA-FLC), \\ Via Antonio Lombardo 11, 26900 Lodi, Italy
}

\begin{abstract}
Despite the great interest paid to protein components in colostrum, fat also plays an important role in the supply of essential nutrients to provide energy, increase metabolism, and protect the newborn calf against microbial infections. This work aimed to elucidate levels of different fat components in colostrum, in particular fatty acid (FA), triglyceride (TG), cholesterol, and phospholipid contents. Colostrum samples from primiparous and multiparous (3-5 lactations) Holstein dams, fed the same ration indoors, were collected on the first $5 \mathrm{~d}$ after parturition, analyzed, and compared with milk samples from the same cows collected at 5 mo of lactation. Fat content during the first $5 \mathrm{~d}$ of milking did not vary. However, the proportion of shortchain saturated FA increased and that of long-chain FA decreased. The concentration of n-3 FA was higher on the first day of calving than on the other days, with clear differences in the number and type of n-3 FA. Conjugated linoleic isomers and trans FA slowly increased from d 1 to 5 , reaching a maximum at 5 mo of lactation. Changes in the distribution profile of TG were observed as lactation progressed, with a shift from a prevalence of high-carbon-number TG $(\mathrm{C} 48-50)$ on d 1 to a bimodal distribution (maxima at C38 and C50) on d 5, characteristic of mid-lactation milk. Cholesterol content was high in the first hours after calving and rapidly decreased within $48 \mathrm{~h}$. Colostrum sampled on d 1 also had a high content of phospholipids. Phosphatidylethanolamine and sphingomyelin were, respectively, lower and higher in the first $5 \mathrm{~d}$ than in mid-lactation milk. The influence of lactation number on colostrum fat composition was also considered and significant results were obtained for all FA groups (except for polyunsaturated and n-6 FA) and TG content.
\end{abstract}

Key words: fatty acid, cholesterol, phospholipid, bovine colostrum

Received September 23, 2013.

Accepted May 5, 2014.

${ }^{1}$ Corresponding author: giovanna.contarini@entecra.it

\section{INTRODUCTION}

Interest in the composition of cow colostrum is usually focused on protein content; in particular, on immunoglobulins and immune factors through which calves acquire passive immunity to prevent disease and mortality (Quigley and Drewry, 1998; Weaver et al., 2000; Stelwagen et al., 2009). In addition to immunological protection immediately after birth, colostrum supplies the neonatal calf with high quality nutrients, including vitamins (especially $\mathrm{A}, \mathrm{D}$, and $\mathrm{E}$ ) and minerals, of which it has low reserves (Ontsouka et al., 2003; Kehoe et al., 2007).

One of the least considered colostrum components is fat, which plays a major role in the supply of constituents to neonatal calves: it provides energy for heat production to maintain body temperature (thermogenesis), and FA oxidation is useful to continue active gluconeogenesis to keep glucose homeostasis (Hammon et al., 2012). Moreover, some FA are beneficial not only for their nutritional properties, but also for specific health effects (Hill et al., 2011). In addition, some digestion products of bovine milk triglycerides (TG) and membrane lipids appear to be effective for their antimicrobial action (Sprong et al., 2001, 2002; Desbois and Smith, 2010).

In studies on colostrum fat, the main attention has been focused on its total content during the first days after calving. Only a few and often dated references deal with the different classes of lipid constituents (Stull et al., 1966; Nardone et al., 1997; Leiber et al., 2011). Specific interest in some acids such as trans isomers, CLA, and branched-chain FA has been shown by other authors (Attaie et al., 1993; Paszczyk et al., 2005).

To our knowledge, only 2 studies have focused on the TG composition of colostrum. A first attempt was done by Parodi (1983), who studied the positional distribution of $\mathrm{FA}$ in $\mathrm{TG}$ in prepartum secretion and early postpartum milk. Laakso et al. (1996) studied the changes in TG composition of colostrum fat of 3 cows during the first week after parturition.

The phospholipid (PL) content and composition within lactations, including d 3 and 7 after parturition, 
were investigated by Bitman and Wood (1990). Phospholipids are mainly located on the milk fat globule membrane, surrounding the fat globules. Glycerophospholipids and sphingolipids are quantitatively the most important PL in milk and comprise a class of biological molecules that play structural and functional roles. Moreover, considerable evidence exists that PL have several beneficial health effects (Contarini and Povolo, 2013), such as the protection against gastrointestinal infections, that is exerted particularly by sphingomyelin (Sprong et al., 2002).

Considering the importance of colostrum for calf nutrition, the composition and quality of its fat fraction cannot be ignored and needs to be updated. The aim of this study was to determine the evolution of the lipid fraction of bovine colostrum of Holstein dams in the first $5 \mathrm{~d}$ after calving compared with milk at 5 mo of lactation. The main lipid constituents, in particular FA, TG, cholesterol, and PL, were analyzed to evaluate the influence of days from birth and lactation number on colostrum fat composition.

\section{MATERIALS AND METHODS}

\section{Sampling}

Milk and colostrum were sampled from Holstein cows belonging to the dairy herd of Centro di Ricerca per le Produzioni Foraggere e Lattiero-Casearie (CRA-FLC, Lodi, Italy). The experimental group consisted of 10 dams, 5 primiparous $(\mathbf{P})$ and 5 multiparous $(\mathbf{M} ; 3-5$ lactations), fed indoors. During the dry period, cows were fed, ad libitum, diets based on hay with the addition of $1 \mathrm{~kg}$ of complementary feed (CP 24.0\%; crude oils and fats $3.6 \%$; crude fiber $7.9 \%$; crude ash $7.6 \%$; sodium $1.16 \%$; magnesium $0.70 \%$ ), which was increased to $3 \mathrm{~kg}$ in the last $10 \mathrm{~d}$ before calving. Immediately after parturition and throughout the lactation period, cows were supplied with a TMR. The daily feed ration consisted of (DM basis) 30\% corn silage, $22 \%$ hay, and $40 \%$ concentrate, with mineral and vitamin supplements. Each cow received $22 \mathrm{~kg}(\mathrm{DM})$. Diet composition on DM basis was $15.5 \% \mathrm{CP}, 4.5 \%$ crude fat, $17 \%$ $\mathrm{ADF}$, and $30 \% \mathrm{NDF}$. The proportion of FA in TMR fat was $\mathrm{C} 14=1.1 \%, \mathrm{C} 16=12.7 \%, \mathrm{C} 18=4.0 \%, \mathrm{C} 18: 1$ $=25.5 \%, \mathrm{C} 18: 2=50.8 \%$, and $\mathrm{C} 18: 3=4.6 \%$. Samples of colostrum were taken from the afternoon milking on the day of calving and once a day for the following $4 \mathrm{~d}$, always at the same time. Milk of the same cows was also sampled at 5 mo after calving. Samples (1 L) were divided into aliquots: one part was refrigerated for chemical composition analysis within $24 \mathrm{~h}$ and the rest was frozen at $-20^{\circ} \mathrm{C}$ immediately after collection and gently thawed at $37^{\circ} \mathrm{C}$ when required for lipid analysis.

\section{Chemical Composition}

Colostrum and milk samples were analyzed with MilkoScan FT2 (Foss, Padova, Italy) for the determination of protein, fat, and lactose contents, using a specific calibration for milk of the same species, according to Romero et al. (2013). Spectra were acquired in the range from 926 to $5,000 \mathrm{~cm}^{-1}$, using a pathlength of 45 $\mu \mathrm{m}$ at a constant temperature of $40 \pm 1^{\circ} \mathrm{C}$. To work within the range of protein calibration, 24-h samples were diluted 1:5 (wt/wt) and 48- to 120-h samples were diluted 1:2 (wt/wt), following the same procedure as in Vetter et al. (2013). Results were expressed as grams per 100 grams of milk.

\section{Fat Extraction}

Total lipids were extracted from colostrum and milk by homogenization with chloroform:methanol $(2: 1$, vol/ vol) according to Folch et al. (1957). The extract was shaken and equilibrated with one-fifth its volume of a saline solution $(0.05 \mathrm{~N}$ of $\mathrm{NaCl})$. The solvent phase was separated, filtered, and evaporated under vacuum.

\section{Triglycerides Composition and Cholesterol Content}

Triglyceride composition, together with cholesterol, was determined according to the Official EC method (European Commission, 2008). The analysis was performed on a Hewlett Packard 5890 gas chromatograph (Agilent, Palo Alto, CA). An Easy 1 (Agilent Technologies) capillary column (4 m long, $0.32 \mathrm{~mm}$ i.d., $0.1 \mu \mathrm{m}$ film thickness) and a flame-ionization detector at $350^{\circ} \mathrm{C}$ were used. Fat samples were dissolved in hexane at a concentration of $3 \mathrm{mg} / \mathrm{mL}$. On-column injection $(1 \mu \mathrm{L})$ was adopted and hydrogen was used as carrier gas at a flow rate of $5 \mathrm{~mL} / \mathrm{min}$. Oven temperature was held at $60^{\circ} \mathrm{C}$ for $2 \mathrm{~min}$, programmed to $340^{\circ} \mathrm{C}$ at a rate of $35^{\circ} \mathrm{C} /$ min, held at $340^{\circ} \mathrm{C}$ for $5 \mathrm{~min}$. Calibration, as required by the Official EC method, was performed by analyzing Certified Reference Material 519 (European Commission, 1997). Triglycerides were identified on the basis of the total number of carbon atoms, excluding glycerol, according to the Official EC method (European Commission, 2008). Results are expressed as mass fraction $(\%)$.

\section{Fatty Acid Composition}

Fatty acids were analyzed and identified according to Povolo et al. (2012) and expressed as grams per 100 grams of FAME. Fatty acids were grouped in different classes. Saturated FA from 4 to 24 carbon atoms, including branched- and odd-chain FA were considered as 
a whole (SFA) and classified according to the number of carbon atoms: from 4 to 10 as short-chain SFA (SCSFA), from 11 to 15 as medium-chain SFA (MCSFA), and from 16 to 24 as long-chain SFA (LCSFA). Unsaturated FA were subdivided into total MUFA, total PUFA, n-3, and n-6 fatty acid groups. Conjugated linoleic acids included rumenic acid (cis-9,trans-11-18:2) and all the isomers of 18:2 conjugated, whereas trans FA grouped all mono- and polyunsaturated trans isomers, excluding CLA.

\section{Phospholipid Composition}

High-performance liquid chromatography with evaporative light scattering detection, according to Avalli and Contarini (2005), was applied to determine PL. The total PL content was expressed as $\mathrm{g} / 100 \mathrm{~g}$ of fat and milk. The most important PL and sphingolipids of milk fat-phosphatidylcholine, phosphatidylethanolamine, phosphatidylinositol, phosphatidylserine, and sphingomyelin - were expressed as percentage of total PL.

\section{Statistical Analysis}

Compositional data obtained on the same subject (cow) in time were evaluated by repeated-measures ANOVA using the MIXED procedure of SAS/STAT software, release 9.3 (2008; SAS Institute Inc., Cary, $\mathrm{NC}$ ). The main effects were calving order (primiparous, $\mathrm{P}$; multiparous, M), time of sampling (24, 48, 72, 96, $120 \mathrm{~h}$ and $5 \mathrm{mo}$ from parturition), and their interaction. The repeated measures on the same subjects determined the block diagonal structure of the residual covariance matrix used in the analyses. For each variable, different covariance structures were tested (SIMPLE, CS, AR1, ANTE1, UN) and the best was chosen according to the Akaike's information criterion. Least squares means (LSM) were calculated and pair-wise tested for each effect in each model. Differences between LSM were determined with the PDIFF option of SAS. For multiple comparisons between means, the Tukey test was used to adjust significance values. Significance was set at $P$ $<0.05$, and a trend was considered for $P<0.10$.

\section{RESULTS AND DISCUSSION}

\section{Chemical Composition}

Mean values of fat, protein, and lactose, grouped by parity and time from calving are shown in Table 1 . No differences were found in the chemical composition when lactation numbers were considered. During lactation, the protein content on $\mathrm{d} 1$ was higher than all the other samplings due to the presence of high concentrations of immunoglobulin and $\beta$-LG (Marnila and Korhonen, 2011). On d 2 of lactation, protein content decreased rapidly to one-third of the value on $\mathrm{d} 1$, in agreement with the literature (Nardone et al., 1997; Elfstrand et al., 2002; Ontsouka et al., 2003). A further reduction was observed at 5 mo of lactation. Fat content did not vary within the first $5 \mathrm{~d}$ of milking $(5.07 \pm 0.207)$, but decreased in milk at 5 mo. In contrast, lactose concentration was lower on d 1 than at all other samplings and rapidly increased on $\mathrm{d} 2$, becoming stable until $\mathrm{d}$ 5 after calving. Higher values were observed in 5-mo milk. Similar fat and lactose changes were observed by Tsioulpas et al. (2007).

In general, the greatest changes in the colostrum composition occurred until d 2 postpartum. In early lactation, the high content of proteins together with the low amount of lactose provide passive immunity and contribute to the reduction of the incidence of diarrhea in calves (Heinrichs and Jones, 2003).

\section{FA Composition}

All FA groups were influenced by lactation number except for PUFA and n-6 FA (Table 2). Multiparous cows had lower content of total SFA than $\mathrm{P}$ cows, but, among this FA category, the LCSFA were higher. Higher concentrations of n-3, CLA, and trans FA were observed in $\mathrm{P}$ cows than in $\mathrm{M}$ cows. No reference data on the influence of parity on FA content of colostrum samples were found. In regard to mid-lactation milk, Kelsey et al. (2003) reported no differences in CLA content between $\mathrm{P}$ and $\mathrm{M}$ animals.

Time-dependent changes in SFA composition of samples are shown in Table 2. Short-chain SFA increased at $48 \mathrm{~h}, 96 \mathrm{~h}$, and $5 \mathrm{mo}$, compared with samples at 24 $\mathrm{h}$. The increase in SCSFA was compensated for by the decline in LCSFA. Samples at 5 mo were not different compared with those at $96 \mathrm{~h}$. These results are in agreement with Leiber et al. (2011) and Stoop et al. (2009), who indicated that LCSFA, associated with mobilization of body fat reserves, were higher in colostrum and decreased continuously during early lactation. Mediumchain SFA and MUFA were similar in 24-h colostrum and 5-mo milk. However, MUFA increased at 72 and 96 $\mathrm{h}$ from calving.

Among the PUFA class, the content of n-6 FA (mainly composed of linoleic acid) of samples at $24 \mathrm{~h}$ was higher than that at $120 \mathrm{~h}$ from calving, but did not differ from that of 5-mo milk. In contrast, the n-3 FA content of samples at $24 \mathrm{~h}$ was higher than that of all the other samples.

As shown by Leiber et al. (2011), a certain level of long-chain PUFA in the colostrum is maintained by the 


\begin{tabular}{|c|c|c|c|c|c|c|c|c|c|c|c|c|}
\hline \multirow[b]{2}{*}{$\begin{array}{l}\text { Item } \\
(\mathrm{g} / 100 \mathrm{~g})\end{array}$} & \multicolumn{2}{|c|}{ Lactation number $^{1}(\mathrm{LN})$} & \multicolumn{6}{|c|}{ Time from calving $(\mathrm{T})$} & \multirow[b]{2}{*}{ SEM } & \multicolumn{3}{|c|}{$P$-value } \\
\hline & $\begin{array}{c}\mathrm{M} \\
(\mathrm{n}=30)\end{array}$ & $\begin{array}{c}\mathrm{P} \\
(\mathrm{n}=30)\end{array}$ & $\begin{array}{c}24 \mathrm{~h} \\
(\mathrm{n}=10)\end{array}$ & $\begin{array}{c}48 \mathrm{~h} \\
(\mathrm{n}=10)\end{array}$ & $\begin{array}{c}72 \mathrm{~h} \\
(\mathrm{n}=10)\end{array}$ & $\begin{array}{c}96 \mathrm{~h} \\
(\mathrm{n}=10)\end{array}$ & $\begin{array}{c}120 \mathrm{~h} \\
(\mathrm{n}=10)\end{array}$ & $\begin{array}{c}5 \text { mo } \\
(\mathrm{n}=10)\end{array}$ & & $\mathrm{LN}$ & $\mathrm{T}$ & $\mathrm{LN} \times \mathrm{T}$ \\
\hline Fat & 5.07 & 4.62 & $5.29^{\mathrm{ab}}$ & $5.32^{\mathrm{ab}}$ & $5.44^{\mathrm{a}}$ & $4.83^{\mathrm{ab}}$ & $4.45^{\mathrm{ab}}$ & $3.74^{\mathrm{b}}$ & 0.318 & 0.27 & 0.04 & 0.14 \\
\hline Protein & 6.60 & 5.98 & $15.88^{\mathrm{a}}$ & $5.86^{\mathrm{b}}$ & $4.41^{\mathrm{b}}$ & $4.20^{\mathrm{b}}$ & $4.08^{\mathrm{b}}$ & $3.30^{\mathrm{c}}$ & 1.042 & 0.27 & $<0.0001$ & 0.17 \\
\hline Lactose & 4.10 & 4.27 & $3.02^{\mathrm{b}}$ & $4.24^{\mathrm{a}}$ & $4.24^{\mathrm{a}}$ & $4.25^{\mathrm{a}}$ & $4.58^{\mathrm{a}}$ & $4.79^{\mathrm{a}}$ & 0.181 & 0.63 & $<0.0001$ & 0.75 \\
\hline
\end{tabular}

${ }^{\mathrm{a}-\mathrm{c}}$ Within each group (parity and time from calving), means within a row with different superscripts differ $(P<0.05)$.

${ }^{1} \mathrm{M}=$ multiparous cows; $\mathrm{P}=$ primiparous cows.

Table 2. Effect of lactation number and hours from calving on FA composition, expressed as percentage of total FAME, of colostrum during the first 5 d after calving and at 5 mo of lactation

\begin{tabular}{|c|c|c|c|c|c|c|c|c|c|c|c|c|}
\hline \multirow[b]{2}{*}{$\begin{array}{l}\text { Fatty acid } \\
\text { class } 1\end{array}$} & \multicolumn{2}{|c|}{ Lactation number ${ }^{2}(\mathrm{LN})$} & \multicolumn{6}{|c|}{ Time from calving $(\mathrm{T})$} & \multirow[b]{2}{*}{ SEM } & \multicolumn{3}{|c|}{$P$-value } \\
\hline & $\begin{array}{c}\mathrm{M} \\
(\mathrm{n}=30)\end{array}$ & $\begin{array}{c}\mathrm{P} \\
(\mathrm{n}=30)\end{array}$ & $\begin{array}{c}24 \mathrm{~h} \\
(\mathrm{n}=10)\end{array}$ & $\begin{array}{c}48 \mathrm{~h} \\
(\mathrm{n}=10)\end{array}$ & $\begin{array}{c}72 \mathrm{~h} \\
(\mathrm{n}=10)\end{array}$ & $\begin{array}{c}96 \mathrm{~h} \\
(\mathrm{n}=10)\end{array}$ & $\begin{array}{c}120 \mathrm{~h} \\
(\mathrm{n}=10)\end{array}$ & $\begin{array}{c}5 \text { mo } \\
(\mathrm{n}=10)\end{array}$ & & LN & $\mathrm{T}$ & $\mathrm{LN} \times \mathrm{T}$ \\
\hline SFA & 62.3 & 68.5 & $66.3^{\mathrm{ab}}$ & $65.2^{\mathrm{ab}}$ & $63.5^{\mathrm{b}}$ & $64.4^{\mathrm{ab}}$ & $66.0^{\mathrm{ab}}$ & $67.8^{\mathrm{a}}$ & 1.04 & 0.01 & 0.03 & 0.001 \\
\hline SCSFA & 7.6 & 10.3 & $5.8^{\mathrm{c}}$ & $8.1^{\mathrm{b}}$ & $9.0^{\mathrm{ab}}$ & $10.5^{\mathrm{a}}$ & $9.7^{\mathrm{ab}}$ & $10.6^{\mathrm{a}}$ & 0.57 & 0.003 & $<0.0001$ & 0.003 \\
\hline MCSFA & 10.8 & 16.1 & $14.1^{\mathrm{ab}}$ & $13.0^{\mathrm{b}}$ & $12.1^{\mathrm{b}}$ & $12.9^{\mathrm{b}}$ & $13.5^{\mathrm{ab}}$ & $15.6^{\mathrm{a}}$ & 0.72 & 0.000 & 0.003 & 0.001 \\
\hline LCSFA & 43.9 & 42.1 & $46.4^{\mathrm{a}}$ & $44.0^{\mathrm{b}}$ & $42.4^{\mathrm{bc}}$ & $40.9^{\mathrm{c}}$ & $42.8^{\mathrm{bc}}$ & $41.6^{\mathrm{c}}$ & 0.58 & 0.02 & $<0.0001$ & 0.11 \\
\hline MUFA & 33.1 & 26.7 & $28.4^{\mathrm{b}}$ & $30.1^{\mathrm{ab}}$ & $31.9^{\mathrm{a}}$ & $31.1^{\mathrm{a}}$ & $29.8^{\mathrm{ab}}$ & $27.5^{\mathrm{b}}$ & 1.06 & 0.008 & 0.01 & 0.000 \\
\hline PUFA & 4.4 & 4.6 & $5.1^{\mathrm{a}}$ & $4.5^{\mathrm{ab}}$ & $4.4^{\mathrm{b}}$ & $4.4^{\mathrm{b}}$ & $4.1^{\mathrm{b}}$ & $4.6^{\mathrm{ab}}$ & 0.14 & 0.55 & 0.001 & 0.03 \\
\hline $\mathrm{n}-3$ & 0.62 & 0.94 & $1.18^{\mathrm{a}}$ & $0.92^{\mathrm{b}}$ & $0.74^{\mathrm{c}}$ & $0.71^{\mathrm{c}}$ & $0.61^{\mathrm{cd}}$ & $0.53^{\mathrm{d}}$ & 0.063 & $<0.0001$ & $<0.0001$ & $<0.0001$ \\
\hline $\mathrm{n}-6$ & 3.5 & 3.2 & $3.6^{\mathrm{a}}$ & $3.3^{\mathrm{ab}}$ & $3.3^{\mathrm{ab}}$ & $3.3^{\mathrm{ab}}$ & $3.0^{\mathrm{b}}$ & $3.5^{\mathrm{a}}$ & 0.11 & 0.32 & 0.006 & 0.25 \\
\hline CLA & 0.29 & 0.43 & $0.23^{\mathrm{d}}$ & $0.27^{\mathrm{cd}}$ & $0.33^{\mathrm{bc}}$ & $0.37^{\mathrm{b}}$ & $0.41^{\mathrm{b}}$ & $0.53^{\mathrm{a}}$ & 0.032 & 0.004 & $<0.0001$ & 0.02 \\
\hline Trans FA & 2.1 & 2.7 & $1.5^{\mathrm{d}}$ & $1.8^{\mathrm{cd}}$ & $2.3^{\mathrm{bc}}$ & $2.5^{\mathrm{bc}}$ & $2.8^{\mathrm{b}}$ & $3.7^{\mathrm{a}}$ & 0.20 & 0.04 & $<0.0001$ & 0.16 \\
\hline
\end{tabular}

${ }^{\mathrm{a}-\mathrm{d}}$ Within each group (parity and time from calving), means within a row with different superscripts differ $(P<0.05)$.

${ }^{1} \mathrm{SCSFA}=$ short-chain SFA; MCSFA = medium-chain SFA; LCSFA = long-chain SFA.

${ }^{2} \mathrm{M}=$ multiparous cows; $\mathrm{P}=$ primiparous cows. 
animal, regardless of diet and level of adipose tissue stores. In fact, some PUFA, and particularly n-3 FA, increase the flexibility and fluidity of cell membranes, are essential for the development of the brain and retina, and support the development of the emerging immune system (Barceló-Coblijn and Murphy, 2009; Hill et al., 2011).

The highest concentration of n-3 FA was due not only to linolenic acid (18:3n-3) but also to high concentrations of 20:4n-3, 20:5n-3 (eicosapentaenoic acid, EPA), 22:4n-3, 22:5n-3 (docosapentaenoic acid, DPA), and 22:6n-3 (docosahexaenoic acid, DHA), which were negligible or absent in 5-mo milk (data not shown).

Conjugated linoleic acid increased from d 1 to 5 after calving and in 5-mo milk, in which the concentration was more than doubled compared with the value on $\mathrm{d}$ 1. In addition, total trans FA, of which 18:1 trans-11 accounts for about $40 \%$, increased during lactation and nearly doubled within $5 \mathrm{~d}$, reaching its highest value in 5-mo milk.

Results obtained were in agreement with data of Paszczyk et al. (2005), who found that the lowest contents of trans 18:1 and 18:2 isomers were in samples taken on the day of calving; on subsequent days of lactation, the contents of these isomers increased.

\section{Triglyceride Composition and Cholesterol}

Triglyceride composition was different in $\mathrm{M}$ and $\mathrm{P}$ samples for almost all constituents (Table 3 ). Triglycerides having 26 to 36 carbon atoms and 42 to 46 carbon atoms were more concentrated in the samples of $\mathrm{P}$ than M cows; the opposite results were observed for TG having higher carbon numbers (50 to 54).

The triglyceride profile changed soon after calving but, in general, colostrum sampled on $\mathrm{d} 1$ and $\mathrm{d} 2$ had a greater proportion of TG with a high carbon number (48-52) than with a low number $(24-36)$. This result was consistent with the highest concentration of LCSFA, which are the main constituents of these TG. Changes in the distribution profile of TG were observed as lactation proceeded: TG with a low carbon number increased until the profile resembled that of cow milk fat with 2 clear maxima located at C38 and C50. These data are in accordance with results by Laakso et al. (1996), who found distinct differences between individuals shortly after calving; the differences decreased during the first week of lactation. Triglycerides in the samples analyzed by Laakso et al. (1996) had a bimodal distribution with an increase in $\mathrm{C} 38$ to $\mathrm{C} 40$ and a decrease in $\mathrm{C} 48$ to $\mathrm{C} 50$ from $\mathrm{d} 1$ to $\mathrm{d} 7$. However, only 3 cows in different lactations were used, and the effect of lactation number on TG distribution was not evaluated.
All TG except for C24, C52, and C54 showed differences as lactation proceeded (Table 3). Changes were observed between samples taken immediately after calving $(24 \mathrm{~h})$ and those collected at $72 \mathrm{~h}$. From 72 $\mathrm{h}$ to $5 \mathrm{mo}$, the concentrations of $\mathrm{C} 42, \mathrm{C} 44, \mathrm{C} 46$, and $\mathrm{C} 48$ increased, that of $\mathrm{C} 38$ decreased, and no variations were observed for the other TG constituents.

Although the precise determination of total cholesterol requires application of a more specific procedure (ISO-IDF, 2006) than the one used in this experiment, values obtained allowed comparison of the different colostrum and milk samples (Table 3). Higher cholesterol concentrations were observed in $\mathrm{P}$ than in $\mathrm{M}$ cows. Moreover, free cholesterol was very high in the first $24 \mathrm{~h}$; it decreased rapidly at $48 \mathrm{~h}$ and more slowly at $72 \mathrm{~h}$. No differences were observed between the last colostrum samples $(120 \mathrm{~h})$ and 5-mo milk. A similar trend throughout the first $7 \mathrm{~d}$ postpartum was observed by Bitman and Wood (1990) in cow colostrum and by Coroian et al. (2013) in buffalo colostrum. The high cholesterol concentration in colostrum meets the needs of newborns because it is an essential component for their development; it is an integral part of cell membranes, where it affects the content of other lipids, specifically sphingomyelin (Dewettinck et al., 2008). Moreover, cholesterol is the precursor of steroid hormones and is responsible for patterning and development of the central nervous system (Pfrieger, 2003).

\section{Phospholipid Composition}

Lactation number did not influence the total concentration of PL fraction and its constituents, except for the percentage of phosphatidylserine (Table 4). The total content of PL of colostrum was higher at $24 \mathrm{~h}$ compared with all other samplings. Literature data on the PL content in the first $24 \mathrm{~h}$ after parturition are not available. The only relevant study was performed by Bitman and Wood (1990), who investigated changes in PL at 3, 7, 42, and $180 \mathrm{~d}$ of lactation and found higher values at $\mathrm{d} 7(1.06 \mathrm{~g} / 100 \mathrm{~g}$ of fat) and $\mathrm{d} 42$ (1.11) than at $d 3(0.72)$ and $d 180(0.56)$.

Among the single PL molecules, phosphatidylcholine, phosphatidylinositol, and phosphatidylserine did not change. In contrast, phosphatidylethanolamine and sphingomyelin contents were lower and higher, respectively, in the first $5 \mathrm{~d}$ after calving than in 5-mo milk. A relatively constant distribution of the PL class during early lactation (3, 7, and $42 \mathrm{~d})$ was also found by Bitman and Wood (1990). However, they observed a lower value of phosphatidylethanolamine at $180 \mathrm{~d}(19.8 \%)$ than at $3 \mathrm{~d}(31.0 \%)$ and a higher sphingomyelin content at $180 \mathrm{~d}(31.4 \%)$ than at $3 \mathrm{~d}(28.7 \%)$. Comparison with the results of Bitman and Wood (1990) should take 
Table 3. Cholesterol and triglyceride composition, expressed as percentage of the total triglyceride content, of colostrum collected during the first $5 \mathrm{~d}$ after calving and at 5 mo of lactation, grouped by parity and time from calving

\begin{tabular}{|c|c|c|c|c|c|c|c|c|c|c|c|c|}
\hline \multirow[b]{2}{*}{ Item } & \multicolumn{2}{|c|}{ Lactation number $^{1}(\mathrm{LN})$} & \multicolumn{6}{|c|}{ Time from calving $(\mathrm{T})$} & \multirow[b]{2}{*}{ SEM } & \multicolumn{3}{|c|}{$P$-value } \\
\hline & $\begin{array}{c}\mathrm{M} \\
(\mathrm{n}=30)\end{array}$ & $\begin{array}{c}\mathrm{P} \\
(\mathrm{n}=30)\end{array}$ & $\begin{array}{c}24 \mathrm{~h} \\
(\mathrm{n}=10)\end{array}$ & $\begin{array}{c}48 \mathrm{~h} \\
(\mathrm{n}=10)\end{array}$ & $\begin{array}{c}72 \mathrm{~h} \\
(\mathrm{n}=10)\end{array}$ & $\begin{array}{c}96 \mathrm{~h} \\
(\mathrm{n}=10)\end{array}$ & $\begin{array}{c}120 \mathrm{~h} \\
(\mathrm{n}=10)\end{array}$ & $\begin{array}{c}5 \text { mo } \\
(\mathrm{n}=10)\end{array}$ & & $\mathrm{LN}$ & $\mathrm{T}$ & $\mathrm{LN} \times \mathrm{T}$ \\
\hline $\begin{array}{l}\text { Cholesterol } \\
\text { Triglycerides }\end{array}$ & 0.49 & 0.59 & $0.92^{\mathrm{a}}$ & $0.58^{\mathrm{b}}$ & $0.44^{\mathrm{c}}$ & $0.50^{\mathrm{bc}}$ & $0.43^{\mathrm{c}}$ & $0.38^{c}$ & 0.045 & 0.001 & $<0.0001$ & 0.16 \\
\hline C24 & 0.06 & 0.11 & 0.06 & 0.07 & 0.08 & 0.11 & 0.09 & 0.08 & 0.017 & 0.22 & 0.55 & 0.88 \\
\hline $\mathrm{C} 26$ & 0.14 & 0.25 & $0.07^{\mathrm{c}}$ & $0.14^{\mathrm{bc}}$ & $0.20^{\mathrm{ab}}$ & $0.28^{\mathrm{a}}$ & $0.25^{\mathrm{a}}$ & $0.24^{\mathrm{ab}}$ & 0.027 & 0.001 & $<0.0001$ & 0.17 \\
\hline $\mathrm{C} 28$ & 0.30 & 0.58 & $0.18^{\mathrm{c}}$ & $0.33^{\mathrm{bc}}$ & $0.45^{\mathrm{ab}}$ & $0.58^{\mathrm{a}}$ & $0.53^{\mathrm{ab}}$ & $0.58^{\mathrm{a}}$ & 0.055 & 0.000 & $<0.0001$ & 0.04 \\
\hline $\mathrm{C} 30$ & 0.60 & 1.10 & $0.39^{c}$ & $0.65^{\mathrm{bc}}$ & $0.84^{\mathrm{ab}}$ & $1.03^{\mathrm{a}}$ & $1.03^{\mathrm{a}}$ & $1.15^{\mathrm{a}}$ & 0.096 & 0.000 & $<0.0001$ & 0.01 \\
\hline $\mathrm{C} 32$ & 1.28 & 2.28 & $1.02^{\mathrm{c}}$ & $1.51^{\mathrm{bc}}$ & $1.74^{\mathrm{ab}}$ & $2.05^{\mathrm{ab}}$ & $2.09^{\mathrm{ab}}$ & $2.26^{\mathrm{a}}$ & 0.176 & 0.001 & $<0.0001$ & 0.01 \\
\hline $\mathrm{C} 34$ & 3.61 & 5.31 & $3.24^{\mathrm{b}}$ & $4.21^{\mathrm{ab}}$ & $4.44^{\mathrm{a}}$ & $4.81^{\mathrm{a}}$ & $4.91^{\mathrm{a}}$ & $5.16^{\mathrm{a}}$ & 0.304 & 0.002 & $<0.0001$ & 0.002 \\
\hline $\mathrm{C} 36$ & 8.57 & 9.71 & $6.92^{\mathrm{b}}$ & $8.98^{\mathrm{a}}$ & $9.78^{\mathrm{a}}$ & $9.95^{\mathrm{a}}$ & $9.75^{\mathrm{a}}$ & $9.48^{\mathrm{a}}$ & 0.359 & 0.02 & $<0.0001$ & 0.007 \\
\hline C38 & 12.10 & 11.78 & $8.58^{\mathrm{c}}$ & $11.65^{\mathrm{b}}$ & $13.58^{\mathrm{a}}$ & $13.45^{\mathrm{a}}$ & $12.70^{\mathrm{ab}}$ & $11.69^{\mathrm{b}}$ & 0.448 & 0.44 & $<0.0001$ & 0.27 \\
\hline $\mathrm{C} 40$ & 8.70 & 9.35 & $6.25^{\mathrm{c}}$ & $8.53^{\mathrm{b}}$ & $10.03^{\mathrm{a}}$ & $10.12^{\mathrm{a}}$ & $9.71^{\mathrm{a}}$ & $9.49^{\mathrm{ab}}$ & 0.359 & 0.08 & $<0.0001$ & 0.09 \\
\hline $\mathrm{C} 42$ & 4.60 & 6.38 & $4.52^{\mathrm{c}}$ & $5.20^{\mathrm{bc}}$ & $5.30^{\mathrm{bc}}$ & $5.61^{\mathrm{ab}}$ & $5.92^{\mathrm{ab}}$ & $6.39^{\mathrm{a}}$ & 0.306 & 0.007 & 0.000 & 0.11 \\
\hline $\mathrm{C} 44$ & 4.27 & 6.09 & $5.64^{\mathrm{ab}}$ & $5.10^{\mathrm{ab}}$ & $4.46^{\mathrm{b}}$ & $4.69^{\mathrm{b}}$ & $5.13^{\mathrm{ab}}$ & $6.08^{\mathrm{a}}$ & 0.309 & 0.009 & 0.001 & 0.22 \\
\hline $\mathrm{C} 46$ & 5.56 & 7.23 & $8.57^{\mathrm{a}}$ & $6.64^{\mathrm{b}}$ & $5.18^{\mathrm{c}}$ & $5.23^{\mathrm{c}}$ & $5.62^{\mathrm{c}}$ & $7.12^{\mathrm{b}}$ & 0.382 & 0.02 & $<0.0001$ & 0.07 \\
\hline $\mathrm{C} 48$ & 9.18 & 9.93 & $13.70^{\mathrm{a}}$ & $10.32^{\mathrm{b}}$ & $7.98^{\mathrm{c}}$ & $7.70^{\mathrm{c}}$ & $8.07^{\mathrm{c}}$ & $9.56^{\mathrm{b}}$ & 0.509 & 0.16 & $<0.0001$ & 0.006 \\
\hline $\mathrm{C} 50$ & 15.70 & 12.85 & $18.84^{\mathrm{a}}$ & $15.33^{\mathrm{b}}$ & $13.42^{\mathrm{c}}$ & $12.83^{\mathrm{c}}$ & $12.88^{\mathrm{c}}$ & $12.34^{\mathrm{c}}$ & 0.657 & 0.003 & $<0.0001$ & 0.05 \\
\hline C52 & 17.18 & 11.28 & 15.20 & 14.57 & 15.10 & 14.37 & 14.3 & 11.84 & 0.978 & 0.006 & 0.08 & 0.01 \\
\hline C54 & 7.66 & 5.16 & 5.90 & 6.19 & 7.00 & 6.68 & 6.58 & 6.11 & 0.503 & 0.03 & 0.52 & 0.004 \\
\hline
\end{tabular}

${ }^{\mathrm{a}-\mathrm{c}}$ Within each group (parity and time from calving), means within a row with different superscripts differ $(P<0.05)$.

${ }^{1} \mathrm{M}=$ multiparous cows; $\mathrm{P}=$ primiparous cows. 
into account that they applied a very different analytical method for the PL determination, based on double separation by thin layer chromatography followed by quantitative densitometry.

The high content of PL, and particularly of sphingomyelin, in the first hours after calving is likely related to the needs of the newborn because these compounds are part of the membrane structure, participate in the transduction of biological signals across the membrane, and probably enhance protection against bacterial gastrointestinal infections (Sprong et al., 2002).

\section{CONCLUSIONS}

The colostrum secreted within $24 \mathrm{~h}$ after calving has a distinct fat composition compared with that produced on d 2 to 4 after calving or in mid-lactation milk. The differences in TG and FA composition observed between the $\mathrm{M}$ and $\mathrm{P}$ colostrum samples suggested that younger and older cows differed in their physiological response to the increased energy requirements due to the onset of lactation. In spite of the large individual variation in its constituents, 24-h colostrum proved to be rich in lipid molecules essential for the newborn; that is, n-3 FA, PL (especially sphingomyelin), and cholesterol. In contrast, trans FA, including CLA, were less concentrated in the first hours after calving. These data may be important when formulating colostrum supplements and replacers.

\section{ACKNOWLEDGMENTS}

This work was realized within the project "ALISALImprovement of the hygienic, salutary and functional properties of food and/or feed commodities" funded by MiPAAF (Ministero delle Politiche Agricole Alimentari e Forestali, Rome, Italy; D.M. 11008/7303/10).

\section{REFERENCES}

Attaie, R., R. L. Richter, and A. H. Reine. 1993. Low molecular weight branched-chain and n-chain fatty acids in caprine and bovine colostrum. J. Dairy Sci. 76:62-69.

Avalli, A., and G. Contarini. 2005. Determination of phospholipids in dairy products by SPE/HPLC/ELSD. J. Chromatogr. A 1071:185-190.

Barceló-Coblijn, G., and E. J. Murphy. 2009. Alpha-linolenic acid and its conversion to longer chain n-3 fatty acids: Benefits for human health and a role in maintaining tissue n-3 fatty acid levels. Prog. Lipid Res. 48:355-374.

Bitman, J., and D. L. Wood. 1990. Changes in milk fat phospholipids during lactation. J. Dairy Sci. 73:1208-1216.

Contarini, G., and M. Povolo. 2013. Phospholipids in milk fat: Composition, biological and technological significance and analytical strategies. Int. J. Mol. Sci. 14:2808-2831. (Review).

Coroian, A., S. Erler, C. T. Matea, V. Mireșan, C. Răducu, C. Bele, and C. O. Coroian. 2013. Seasonal changes of buffalo colostrum: Physicochemical parameters, fatty acids and cholesterol variation. Chem. Cent. J. 7:40. 
Desbois, A. P., and V. J. Smith. 2010. Antibacterial free fatty acids: Activities, mechanisms of action and biotechnological potential. Appl. Microbiol. Biotechnol. 85:1629-1642.

Dewettinck, K., R. Rombaut, N. Thienpont, T. T. Le, K. Messens, and J. van Camp. 2008. Nutritional and technological aspects of milk fat globule membrane material. Int. Dairy J. 18:436-457.

Elfstrand, L., H. Lindmark-Månsson, M. Paulsson, L. Nyberg, and B. Akesson. 2002. Immunoglobulins, growth factors and growth hormone in bovine colostrum and the effects of processing. Int. Dairy J. 12:879-887.

European Commission. 1997. Commission of the European Communities: The certification of the triglyceride contents of an anhydrous butter fat reference material with additional value for free cholesterol. Report 17613:1997.

European Commission. 2008. Commission Regulation (EC) No 273/2008 of 5 March 2008 laying down detailed rules for the application of Council Regulation (EC) No 1255/1999 as regards methods for the analysis and quality evaluation of milk and milk products. Annex XX. Reference method for the determination of milk fat purity by gas chromatographic analysis of triglyceridesRevision 2. Off. J. Eur. Union L 88:97-112.

Folch, J., M. Lees, and G. H. S. Stanley. 1957. A simple method for the isolation and purification of total lipids from animal tissues. J. Biol. Chem. 226:497-509.

Hammon, H. M., J. Steinhoff-Wagner, U. Schönhusen, C. C. Metges, and J. W. Blum. 2012. Energy metabolism in the newborn farm animal with emphasis on the calf: Endocrine changes and responses to milk-born and systemic hormones. Domest. Anim. Endocrinol. 43:171-185.

Heinrichs, A. J., and C. M. Jones. 2003. Feeding the newborn dairy calf. College of Agricultural Sciences Agricultural Research and Cooperative Extension, The Pennsylvania State University. Accessed Aug. 22, 2013. http://pubs.cas.psu.edu/freepubs/pdfs/ ud013.pdf.

Hill, T. M., M. J. VandeHaar, L. M. Sordillo, D. R. Catherman, H. G. Bateman II, and R. L. Schlotterbeck. 2011. Fatty acid intake alters growth and immunity in milk-fed calves. J. Dairy Sci. 94:39363948.

ISO-IDF. 2006. Anhydrous milk fat-Determination of sterol composition by gas liquid chromatography (Reference method). International Standard ISO 12078-IDF 159. International Organization of Standardization (ISO), Geneva, Switzerland; International Dairy Federation (IDF), Brussels, Belgium.

Kehoe, S. I., B. M. Jayarao, and A. J. Heinrichs. 2007. A survey of bovine colostrum composition and colostrum management practices on Pennsylvania dairy farms. J. Dairy Sci. 90:4108-4116.

Kelsey, J. A., B. A. Corl, R. J. Collier, and D. E. Bauman. 2003. The effect of breed, parity, and stage of lactation on conjugated linoleic acid (CLA) in milk fat from dairy cows. J. Dairy Sci. $86: 2588-2597$.

Laakso, P., P. Manninen, J. Mäkinen, and H. Kallio. 1996. Postparturition changes in the triacylglycerols of cow colostrum. Lipids 31:937-943.

Leiber, F., R. Hochstrasser, H.-R. Wettstein, and M. Kreuzer. 2011 Feeding transition cows with oilseeds: Effects on fatty acid composition of adipose tissue, colostrum and milk. Livest. Sci. 138:1-12.
Marnila, P., and H. Korhonen. 2011. Colostrum. Pages 591-597 in Encyclopedia of Dairy Sciences. Vol. 3. 2nd ed. J. W. Fuquay, P. F. Fox and P. L. H. McSweeney, ed. Academic Press, San Diego, CA.

Nardone, A., N. Lacetera, U. Bernabucci, and B. Ronchi. 1997. Composition of colostrum from dairy heifers exposed to high air temperatures during late pregnancy and the early postpartum period. J. Dairy Sci. 80:838-844.

Ontsouka, C. E., R. M. Bruckmaier, and J. W. Blum. 2003. Fractionized milk composition during removal of colostrum and mature milk. J. Dairy Sci. 86:2005-2011.

Parodi, P. W. 1983. Positional distribution of fatty acids in triglycerides from prepartum mammary gland secretion and early postpartum milk. J. Dairy Sci. 66:913-919.

Paszczyk, B., Z. Zegarska, and Z. Borejszo. 2005. The contents of trans fatty acids and CLA in cow colostrums and milk fat in the early lactation period. Czech J. Food Sci. 23:159-165.

Pfrieger, F. W. 2003. Cholesterol homeostasis and function in neurons of the central nervous system. Cell. Mol. Life Sci. 60:1158-1171.

Povolo, M., V. Pelizzola, G. Lombardi, A. Tava, and G. Contarini. 2012. Hydrocarbon and fatty acid composition of cheese as affected by the pasture vegetation type. J. Agric. Food Chem. 60:299-308.

Quigley, J. D., III, and J. J. Drewry. 1998. Nutrient and immunity transfer from cow to calf pre- and postcalving. J. Dairy Sci. 81:2779-2790.

Romero, T., M. C. Beltrán, M. Rodríguez, A. M. De Olives, and M. P. Molina. 2013. Goat colostrum quality: Litter size and lactation number effects. J. Dairy Sci. 96:7526-7531.

Sprong, R. C., M. F. E. Hulstein, and R. Van Der Meer. 2001. Bactericidal activities of milk lipids. Antimicrob. Agents Chemother. 45:1298-1301.

Sprong, R. C., M. F. E. Hulstein, and R. Van Der Meer. 2002. Bovine milk fat components inhibit food-borne pathogens. Int. Dairy J. 12:209-215.

Stelwagen, K., E. Carpenter, B. Haigh, A. Hodgkinson, and T. T. Wheeler. 2009. Immune components of bovine colostrum and milk. J. Anim. Sci. 87(13 Suppl.):3-9.

Stoop, W. M., H. Bovenhuis, J. M. L. Heck, and J. A. M. van Arendonk. 2009. Effect of lactation stage and energy status on milk fat composition of Holstein-Friesian cows. J. Dairy Sci. 92:1469-1478.

Stull, J. W., W. H. Brown, C. Valdez, and H. Tucker. 1966. Fatty acid composition of milk. III. Variation with stage of lactation. J. Dairy Sci. 49:1401-1405.

Tsioulpas, A., A. S. Grandison, and M. J. Lewis. 2007. Changes in physical properties of bovine milk from the colostrum period to early lactation. J. Dairy Sci. 90:5012-5017.

Vetter, A., A. Argüello, C. Baumrucker, and R. M. Bruckmaier. 2013. Fractional milking distribution of immunoglobulin G and other constituents in colostrum. J. Dairy Sci. 96:5919-5922.

Weaver, D. M., J. W. Tyler, D. C. VanMetre, D. E. Hostetler, and G. M. Barrington. 2000. Passive transfer of colostral immunoglobulins in calves. J. Vet. Intern. Med. 14:569-577. 